\title{
Correction to: Barriers and Facilitators of Disclosing Domestic Violence to the UK Health Service
}

\author{
Rebecca L. Heron ${ }^{1,2,3} \cdot$ Maarten C. Eisma ${ }^{2} \cdot$ Kevin Browne $^{3}$ \\ Published online: 7 June 2021 \\ (c) The Author(s) 2021
}

\section{Correction to: Journal of Family Violence https://doi.org/10.1007/s10896-020-00236-3}

The article Barriers and Facilitators of Disclosing Domestic Violence to the UK Health Service, written by Rebecca L. Heron, Maarten C. Eisma, and Kevin Browne, was originally published Online First without Open Access. With the author(s)' decision to opt for Open Choice the copyright of the article changed on May 12, 2021 to $\odot$ The Author(s) 2021 and the article is forthwith distributed under a Creative Commons Attribution 4.0 International License, which permits use, sharing, adaptation, distribution and reproduction in any medium or format, as long as you give appropriate credit to the original author(s) and the source, provide a link to the Creative Commons licence, and indicate if changes were made. The images or other third party material in this article are included in the article's Creative Commons licence, unless indicated otherwise in a credit line to the material. If material is not included in the article's Creative Commons licence and your intended use is not permitted by statutory regulation or exceeds the permitted use, you will

The original article can be found online at https://doi.org/10.1007/ s10896-020-00236-3.

Rebecca L. Heron

HeronR@uhv.edu

Maarten C. Eisma

m.c.eisma@rug.nl

Kevin Browne

kevin.browne@nottingham.ac.uk

1 Department of Arts \& Sciences, University of HoustonVictoria, 3007 N. Ben Wilson, Victoria, TX 77901, USA

2 Department of Behavioural and Social Sciences, University of Groningen, Groningen, Netherlands

3 Department of Medicine \& Health Sciences, University of Nottingham, Nottingham, UK need to obtain permission directly from the copyright holder. To view a copy of this licence, visit http://creativecommons. org/licenses/by/4.0.

The original article has been corrected.

Open Access This article is licensed under a Creative Commons Attribution 4.0 International License, which permits use, sharing, adaptation, distribution and reproduction in any medium or format, as long as you give appropriate credit to the original author(s) and the source, provide a link to the Creative Commons licence, and indicate if changes were made. The images or other third party material in this article are included in the article's Creative Commons licence, unless indicated otherwise in a credit line to the material. If material is not included in the article's Creative Commons licence and your intended use is not permitted by statutory regulation or exceeds the permitted use, you will need to obtain permission directly from the copyright holder. To view a copy of this licence, visit http://creativecommons.org/licenses/by/4.0/.

Publisher's Note Springer Nature remains neutral with regard to jurisdictional claims in published maps and institutional affiliations. 